\title{
Croton (Euphorbiaceae) in the State of São Paulo, Brazil: an update
}

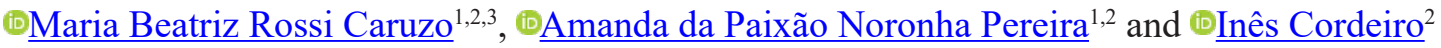

Received: 4 October 2018; accepted: 27 March 2019

How to cite: Caruzo, M.B.R., Pereira, A.P.N. \& Cordeiro, I. 2019. Croton (Euphorbiaceae) in the State of São Paulo, Brazil: an update. Hoehnea 46: e912018. http://dx.doi.org/10.1590/2236-8906-91/2018.

ABSTRACT - (Croton (Euphorbiaceae) in the State of São Paulo, Brazil: an update). An updated key for Croton species in the State of São Paulo is presented as well as new occurrences of the genus and the reestablishment of Croton thermarum Müll. Arg. For those species of Croton that were not included in previous studies in the State of São Paulo, we provided: the original publication, synonymy, global geographic distribution, vegetation type, and a representative herbarium collection. This study increases the number of the known species of Croton species in São Paulo State to 40 and contributes to the knowledge of the genus in Brazil.

Keywords: Flora of São Paulo, floristics, new records, taxonomy

RESUMO - (Croton (Euphorbiaceae) no Estado de São Paulo, Brasil: uma atualização). É apresentada uma chave de identificação atualizada para as espécies de Croton encontradas no Estado de São Paulo, bem como novas ocorrências do gênero e o restabelecimento de Croton thermarum Müll.Arg. Para as espécies ainda não tratadas em estudos prévios sobre o gênero no Estado são apresentados: publicação original, sinônimos, distribuição geográfica total e tipo de vegetação de sua ocorrência, além da citação de uma coleção de herbário. O presente estudo aumenta para 40 o número de espécies de Croton no Estado de São Paulo e contribui para o conhecimento do gênero no Brasil.

Palavras-chave: Flora de São Paulo, florística, novas ocorrências, taxonomia

\section{Introduction}

Croton L. (Euphorbiaceae) is considered one of the biggest Angiosperm genera, with about 1.200 species distributed worldwide (Berry et al. 2005). In Brazil, Croton is also one of the largest genera, with 316 species and a high degree of endemism (BFG 2015). The genus occurs in almost all kinds of habitats but has a great number of species growing in open vegetation and disturbed sites (Gomes-Pompa 1971, Caruzo et al. 2011, van Ee et al. 2011).

Besides their great morphological variation, species of the genus can be easily recognized by the presence of stellate to lepidote trichomes, clear to reddish latex, basilaminar or acropetiolar glands, senescent leaves that turn orange before abscission, and thyrsoid inflorescences of unisexual flowers (Riina et al. 2009).

Here we present an update to the knowledge of Croton in São Paulo, a key for all Croton species occurring at the State as well as the reestablishment of Croton thermarum Müll.Arg.

\section{Material and methods}

This study was based on field observations and the analysis of herbarium collections from: ESA, MBM, $\mathrm{R}, \mathrm{RB}, \mathrm{SP}, \mathrm{SPF}, \mathrm{UEC}$ (abbreviations according to Thiers 2018, continuously updated). Type specimens were analyzed through images available mainly at the JSTOR Global Plants website (http://plants.jstor.org/). Morphological terms used in the key for the species follows Hickey (1973), Stearn (1992), Webster (1993), and Webster et al. (1996).

\section{Results and Discussion}

Although Croton continues to be the most diverse genus of Euphorbiaceae in São Paulo (now with 40 species), it is outnumbered by other much

1. Universidade Federal de São Paulo, Campus Diadema, Departamento de Ecologia e Biologia Evolutiva, 04021-001 Diadema, SP, Brasil

2. Instituto de Botânica, Av. Miguel Estéfano, 3.687, 04301-902, São Paulo, SP, Brasil

3. Corresponding author: mbrcaruzo@gmail.com 
richer genera of Angiosperms listed in Wanderley et al. (2011), such as Eugenia (113), Vernonia (106) and Solanum (102). In São Paulo, species of Croton varies from herbs to large trees and occurs in wet to dry forests, 'cerrados' and altitude fields. A detailed description of the genus can be found in Caruzo \& Cordeiro (2007).

Caruzo \& Cordeiro (2007) listed 37 species of Croton in São Paulo State. However, the recent discover of Croton echinocarpus Müll. Arg. has increased the number of known species in the State to 38 (Caruzo \& Santos 2015). In addition, during taxonomic studies conducted on the genus Croton in Brazil, we found new records for São Paulo. Thus, the present work increases the number of species for the State to 40 (table 1), with the occurrence of Croton chaetophorus Müll.Arg. and Croton reitzii L.B.Sm. \& Down in São Paulo. Besides the new records for the State, we also reestablished the name Croton thermarum Müll.Arg.

Updated key to the species of Croton in São Paulo State (modified from Caruzo \& Cordeiro, 2007)

1. Leaves with acropetiolar or basilaminar glands.

2. Styles 2-fid (with 6 terminal tips)

3. Prostate subshrubs. Leaves orbiculate to reniform, about $1.0 \mathrm{~cm}$ long.

3. Trees to shrubs, erect. Leaves ovate, ovate-lanceolate to cordiform, $2.0 \mathrm{~cm}$ long or more

4. Inflorescences with proximal cymules of pistillate and staminate flowers, distal ones exclusively staminate

5. Leaves ovate-lanceolate. Stipitate acropetiolar glands C. macrobothrys subsp. macrobothrys

5. Leaves ovate to cordiform. Sessile acropetiolar glands

6. Plants with stellate trichomes. Bracts triangular. Pistillate flowers with petals reduced to a conspicuous globose to patelliform glands C. gracilipes

6. Plants with dendritic trichomes, adpressed-stellate or stellate. Bracts lanceolate. Pistillate flowers with filiform petals.

7. Leaves ovate. Capsule obovate, strongly trigone; seeds subglobose with a smooth testa ... C. piptocalyx

7. Leaves cordiform. Capsule subglobose to globose; seeds globose with a verrucose to costate testa. 8. Stipules subulate, acute apex, not foliaceous. Capsule echinate-muricate ............ C. echinocarpus 8. Stipules ovate, acuminate apex, foliaceous. Capsule smooth C. urucurana

4. Inflorescences with proximal cymules pistillate and distal ones staminate.

9. Leaf margin entire to finely serrate. Pistillate flowers subcampanulate; sepals equal in size. Columella with three prominent inflated lobes.

10. Inflorescences congested. Petals of pistillate flowers filiform C. reitzii

10. Inflorescences lax. Petals of pistillate flowers reduced to globose glands.

11. Indumentum glabrescent. Stipules deltoid. Leaves with stipitate acropetiolar glands.

Staminate flowers pedicellate C. leptobotryus

11. Indumentum pubescent. Stipules lanceolate. Leaves with sessile acropetiolar glands.

Staminate flowers sessile C. sanctae-crucis

9. Leaf margin serrate to dentate. Pistillate flowers subcampanulate to campanulate, sepals unequal in size. Columella lacking prominent inflated lobes

12. Leaf margin dentate. Inflorescence axis without flowers between proximal distal cymules; bracts without glands C. lundianus

12. Leaf margin serrate. Inflorescence axis with proximal distal cymules contiguous; bracts with lageniform glands.

13. Young branches pubescent, stellate trichomes. Bracts with sessile lageniform glands. Ovary pilose C. glandulosus

13. Young branches hirsute, stellate and stellate-porrect trichomes. Bracts with shortly stipitate lageniform glands. Ovary hirsute C. hirtus

2. Styles 4-fid or more (12 or more terminal tips)

14. Inflorescences with pistillate cymules proximal and staminate distal 
15. Young branches pubescent. Leaves with entire margin, without glands; venation eucamptodromous; basilaminar glands adpressed, sometimes covered by trichomes. Pistillate petals subulate, with glands at the apex

C. thermarum

15. Young branches hirsute. Leaves with dentate margin, with glands in the sinuses; venation cladodromous; basilaminar or acropetiolar glands not adpressed and not covered by trichomes. Pistillate petals absent or inconspicuous

16. Inflorescence axis without flowers between proximal distal cymules. Pistillate flowers sessile; sepals 6 ............................................................................................... sclerocalyx

16. Inflorescence axis with proximal distal cymules contiguous. Pistillate flowers pedicellate; sepals 5 C. antisyphiliticus

14. Inflorescences with proximal cymules of pistillate and staminate flowers, distal cymules of staminate flowers.

17. Leaf glands sessile

18. Leaves ovate, base cuneate to slightly truncate. Staminate flowers campanulate. Pistillate flowers pedicellate; calyx lobes sometimes with dark brown indument C. rottlerifolius

18. Leaves ovate to ovate-lanceolate, base cordate Staminate flowers rotate. Pistillate flowers subsessile; calyx lobes with whitish indument

17. Leaf glands stipitate

19. Plants with lepidote trichomes

20. Indument rufous-silvery; branchlets angular. Pistillate flowers flask-shaped; calyx lobes not accrescent in fruit C. salutaris

20. Indument silvery; branchlets cylindrical. Pistillate flowers campanulate; calyx lobes strongly accrescent in fruit C. hemiargyreus

19. Plants with stellate, adpressed-stellate or dendritic trichomes

21. Stamens $80-130$ C. vulnerarius

21. Stamens $18-60$

22. Leaves widely elliptical to obovate; margin crenate. Stamens ca. 18. Pistillate flowers reduplicate-valvate; sepals rounded..... C. priscus

22. Leaves ovate to cordate; margin serrate. Stamens 50-60. Pistillate flowers valvate; sepals ovate to ovate-lanceolate

23. Pistillate flowers slightly campanulate, sessile to subsessile; calyx lobes ovate, foliaceous, ca. $8 \mathrm{~mm}$ long; styles slightly joined at the base C. alchorneicarpus

23. Pistillate flowers rotate, usually pedicellate, rarely subsessile; calyx lobes ovate-lanceolate, ca. $3 \mathrm{~mm}$ long; styles free

C. celtidifolius

1. Leaves without glands (except in C. organensis, where the glands are usually maculate and very difficult to see)

24. Staminate flowers with three cuculate sepals and the other two flat. Pistillate ones with three bigger and laciniate sepals and the other two inconspicuous and entire.

25. Subshrubs with xylopodium. Leaves oblong, lanceolate, orbiculate to ovate. Seeds with smooth testa C. didrichsenii

25. Subshrubs to shrubs without xylopodium. Leaves cordate, widely elliptical, lanceolate to ovatelanceolate. Seeds with reticulate testa

26. Indument whitish to ferrugineous; styles 4 -fid ( 12 terminal tips) C. triqueter

26. Indument whitish and darkish; styles 2 -fid (6 terminal tips)

C. fuscescens

24. Staminate flowers with five flat sepals. Pistillate ones with 5 entire sepals of the same size

27. Styles 2-fid (with 6 terminal tips)

28. Plants from 'cerrado' s.s., indument exclusively of stellate trichomes

29. Stamens ca. 18. Capsule globose, pilose to hirsute. Seeds smooth . C. grandivelus

29. Stamens ca. 11. Capsule subglobose to ellipsoid, glabrescent. Seeds slightly warty C. pedicellatus

28. Plants from grasslands or high montain grasslands, indumentum of stellate, adpressedstellate or lepidote trichomes 
30. Leaves covered by stellate trichomes on the upper surface and adpressed-stellate or lepidote trichomes on the lower surface.

31. Leaves lanceolate. Pistillate flowers campanulate; calyx lobes lanceolate to spathulate; styles 2-fid to twice 2-fid C. serpyllifolius

31. Leaves elliptical to ovate-lanceolate. Pistillate flowers subcampanulate; calyx lobes ovate to rounded; styles always 2-fid C. ceanothifolius

30. Leaves covered only by lepidote trichomes

32. Leaves usually with upper surface glabrous and lower surface lepidote. Pistillate flowers campanulate, calyx lobes ovate-lanceolate to oblong C. dichrous

32. Leaves lepidote on both surfaces. Pistillate flowers subcampanulate, calyx lobes elliptical, ovate to obovate C. erythroxyloides

27. Styles 4-fid or more (12 or more terminal tips)

33. Pistillate flowers with sepals covered by glandular trichomes

34. Bracts entire, lanceolate-rhombic; without glandular trichomes. Sepals of pistillate flowers entirely covered by glandular trichomes ............................................ C. chaetophorus

34. Bracts laciniate, linear; margin with glandular trichomes. Sepals of pistillate flowers with glandular trichomes restricted to the margin

35. Leaves tomentose on lower surface, elliptic to ovate-lanceolate, venation eucamptodromous. Stipules laciniate C. serratifolius

35. Leaves pubescent to glabrescent on lower surface, rhombic to obovate, venation acrodromous. Stipules entire C. fuscus

33. Pistillate flowers with the sepals without glandular trichomes

36. Inflorescence congested, comose. Pistillate sepals lanceolate, margin glandularlacerate; petals inconspicuous C. heterodoxus

36. Inflorescence lax, not comose. Pistillate sepals oblong to ovate-lanceolate, margin entire; petals filiform or absent

37. Branchlets flattened. Staminate flowers campanulate to subcampanulate. Pistillate flowers sessile to subsessile; petals absent

38. Stipules subulate, margin with glands. Inflorescences with all cymules of the same type. Pistillate flowers campanulate, calyx lobes ovate to ovate-lanceolate

C. compressus

38. Stipules linear, margin without glands. Inflorescences with proximal cymules of pistillate and staminate flowers, distal cymules of staminate flowers. Pistillate flowers flask-shaped, calyx lobes rhomboidal C. organensis

37. Branchlets cylindrical. Staminate flowers rotate to subcampanulate. Pistillate flowers pedicellate; petals filiform

39. Trees covered by stellate, adpressed-stellate and trichomes. Pistillate flowers rotate. Capsule globose, verrucose. Seeds globose, smooth C. floribundus

39. Shrubs covered by lepidote trichomes. Pistillate flowers campanulate. Capsule subglobose, smooth. Seeds oblong, slightly ribbed C. tricolor

Croton chaetophorus Müll.Arg., Linnaea 34: 130. 1865. Type: BRAZIL. "Brasilia meridionalis", s.d., A.F. Regnell, s.n. (syntype: B [n.v.]); idem, F. Sellow, s.n. (s: B [n.v.]); idem, L. Riedel, s.n. (syntype: B [n.v.]). (Illustrations in Smith et al. 1988)

Shrubs about $1.5 \mathrm{~m}$ tall, in open vegetation. Occurs in south (PR, SC) and southeastern Brazil (MG, SP).

In the previous treatment of Croton from the State of São Paulo (Caruzo \& Cordeiro 2007), specimens of $C$. chaetophorus were misidentified as C. serratifolius Baill. (e.g. Paula-Souza et al. 3655). In fact, C. chaetophorus is similar to C. serratifolius, once both species have stellate trichomes on branchlets and leaves, glandular trichomes on pistillate flower calyx lobes and styles 4-fid. However, the two species can be differentiated by leaf shape (ovate to ovatelanceolate in C. chaetophorus vs. elliptic to oblong in C. serratifolius) and stipules (laciniate with glandular trichomes at the base in $C$. chaetophorus vs. entire 
Table 1. Updated list of Croton from São Paulo.

\begin{tabular}{|c|c|}
\hline Species & Voucher number \\
\hline Croton alchorneicarpus Croizat & Riina 1532 (SP) \\
\hline C. antisyphiliticus Mart. & Duarte 53 (SP) \\
\hline C. ceanothifolius Baill. & Caruzo 70 (SP, SPF, WIS) \\
\hline C. celtidifolius Baill. & Santos 40 (SP) \\
\hline C. chaetophorus Müll.Arg. & Paula-Souza 3655 (ESA, HUEFS, SP) \\
\hline C. compressus Lam. & Rossi 1090 (SP, WIS) \\
\hline C. dichrous Müll.Arg. & Caruzo 69 (SP, SPF, WIS) \\
\hline C. didrichsenii Webster & $\begin{array}{c}\text { Souza } 2422 \text { (BHCB, ESA, FUEL, IAN, SPSF, MBM, PEL, } \\
\text { RB, SP) }\end{array}$ \\
\hline C. echinocarpus Müll.Arg. & Santos $2(\mathrm{SP})$ \\
\hline C. erythroxyloides Baill. & Caruzo 74 (SP, SPF, WIS) \\
\hline C. floribundus Spreng. & Santos 3 (SP) \\
\hline C. fuscescens Spreng. & Caruzo 1 (SP) \\
\hline C. fuscus (Didr.) Müll.Arg. & Kuhlmann s.n. (SP 69956) \\
\hline C. glandulosus $\mathrm{L}$. & Caruzo 25 (SP) \\
\hline C. glechomifolius Müll.Arg. & Chung 127 (SP) \\
\hline C. gracilipes Baill. & Santos 44 (SP) \\
\hline C. grandivelus Baill. & Caruzo 34 (SP) \\
\hline C. hemiargyreus Müll.Arg. & Santos 42 (SP) \\
\hline C. heterodoxus & Elias $258(\mathrm{SP})$ \\
\hline C. hirtus L'Hér. & Torres $116(\mathrm{IAC}, \mathrm{SP})$ \\
\hline C. leptobotryus Müll.Arg. & Mello-Silva 41 (SP, SPF) \\
\hline C. lundianus (Didr.) Müll.Arg. & Caruzo 64 (SP) \\
\hline C. macrobothrys subsp. macrobothrys Baill. & Santos 32 (SP) \\
\hline C. organensis Baill. & Caruzo 82 (SP, SPF, WIS) \\
\hline C. pedicellatus Kunth & Pinheiro 727 (HRCB, SP) \\
\hline C. piptocalyx Müll.Arg. & Caruzo 79 (SP, WIS) \\
\hline C. priscus Croizat & Caruzo 63 (SP) \\
\hline C. reitzii L.B.Sm. \& Downs & Cielo-Filho 1149 (SP, SPSF) \\
\hline C. rottlerifolius Baill. & Santos 41 (SP) \\
\hline C. salutaris Casar. & Caruzo 81 (SP, SPF, WIS) \\
\hline C. sanctae-crucis S. Moore & Pereira-Noronha 1542 (SP, UEC) \\
\hline C. sclerocalyx (Didr.) Müll.Arg. & Caruzo 43 (SP) \\
\hline C. serpyllifolius Baill. & Souza 7030 (ESA, SP) \\
\hline C. serratifolius Baill. & Souza 8807 (ESA, SP) \\
\hline C. sphaerogynus Baill. & Caruzo 65 (SP, WIS) \\
\hline C. thermarum Müll.Arg. & Garcia 687 (HRCB, PMSP, SP, SPF, UEC) \\
\hline C. tricolor Klotzsch ex Baill. & Caruzo 85 (SP) \\
\hline Croton triqueter Lam. & Caruzo 27 (SP) \\
\hline C. urucurana Baill. & Santos $5(\mathrm{SP})$ \\
\hline C. vulnerarius Baill. & Santos 56 (SP) \\
\hline
\end{tabular}


with glandular trichomes along the margin in $C$. serratifolius).

Selected specimen examined: BRAZIL. SÃo PAUlo: Itararé, $17 \mathrm{~km}$ de Itararé para Bom Sucesso de Itararé, 13-XI-2003, J. Paula-Souza et al. 3655 (ESA, HUEFS, SP).

Croton echinocarpus Müll.Arg., Linnaea 34: 88. 1865. Croton verrucosus Radcl.-Sm. \& Govaerts, Kew Bull 52: 198. 1997. nom. super. Type: BRAZIL. s.d.,s. col.,s.n. (holotype: G-DC 00311425!).(Figures in Caruzo \& Santos 2015)

Croton echinocarpus is endemic from the Atlantic Rain Forest and is found mainly in montane wet forests from southeastern Brazil (ES, MG, RJ, SP) (Silva et al. 2017). The ornamentation of the epicarp (echinate-muricate, with projections ending in a stipitate-multiradiate trichome) is a diagnostic characteristic to the species.

Among all species of Croton from São Paulo State, C. echinocarpus is most similar to C. celtidifolius Baill. However, both species can be separated by their leaf glands (sessile in C. echinocarpus vs. stipitate to shortly stipitate in C. celtidifolius), styles division (2-fid and united in C. echinocarpus vs. 4-fid and free in C. celtidifolius), and epicarp ornamentation (echinate-muricate in C. echinocarpus vs. warty in C. celtidifolius).

Selected specimen examined: BRAZIL. São Paulo: Atibaia, 28-III-2014, R.F. Santos and O.L.M. Silva 2 (SP).

Croton reitzii L.B.Sm. \& Downs, Sellowia 11: 152. 1959. Type: BRAZIL. Santa Catarina: Canoinhas, $19 \mathrm{~km}$ ao oeste de Canoinhas no caminho para Porto União, 17-XII-1956, L.B. Smith \& R. Reitz 8590 (holotype: US 2249814!; isotypes: K000254430, NY 00262942, R 000200949, UC 1079899).(Illustrations in Smith et al. 1988)

Shrubs about $1.5 \mathrm{~m}$ tall, growing along borders of Araucaria forest, rarely in open vegetation, in south (PR, RS, SC) and southeastern Brazil (SP). The leaves with a pair of sessile glands and the inflorescences congested are important characteristics for species recognition (see illustrations in Smith et al. 1988).

Smith et al. (1988) recorded Croton reitzii for southern Brazil. Here we first record the species for São Paulo State, extending its distribution range.

The species is most morphologically similar to C. lanatus (a species endemic to southern Brazil), however both species can be distinguished by leaf shape (lanceolate in $C$. reitzii vs. ovate to ovatelanceolate in C. lanatus), bracts morphology (without glands at the base in $C$. reitzii vs. with a pair of glands at the base in C. lanatus), and inflorescences (congested in C. reitzii vs. lax in C. lanatus).

Selected specimen examined: BRAZIL. SÃo PAUlo: Itapeva, 30-IX-2010, R. Cielo-Filho, J.B. Baitello and C.R. Lima 1149 (SP, SPSF).

Croton thermarum Müll.Arg., Fl. Bras. 11(2): 151. 1873. Type: BRAZIL. Minas Gerais: "prope Caldas, in campis juxta thermas", 1847, A.F. Regnell 1084 (holotype: G 00434665!; isotypes: BR 0000008760623!,BR0000008760654!,P00623517!, S 0712769!, S R-10582!, US 00109775!, US 00902149!). (Illustrations in Caruzo \& Cordeiro 2007)

Shrubs to subshrubs mainly from open vegetation in Brazil (MG, PR, SP). The species can be recognized due to its basilaminar glands and the presence of rosulate trichomes covering the ovary and fruit.

Croton thermarum was synonymized to C. lanatus Lam. var. lanatus by Caruzo \& Cordeiro (2007), mainly due to their similar trichomes in branches, and leaves with basilaminar glands extremely adpressed. However, both species can be differentiated by styles division (4-fid in C. thermarum vs. 2-fid in C. lanatus var. lanatus) and ovary trichomes (rosulate in $C$. thermarum vs. stellate in $C$. lanatus var. lanatus). In addition, $C$. lanatus var. lanatus occurs in sympatry with $C$. thermarum only in Paraná State, where its northern boundary of distribution is located. Therefore, we here reestablished the name $C$. thermarum.

Selected specimen examined: BRAZIL. São PAUlo: São Paulo, VII-1995, R.J.F. Garcia et al. 687 (HRCB, PMSP, SP, SPF, UEC).

\section{Acknowledgments}

Financial support was provided to MBRC (process 441049/2014-1) by 'Conselho Nacional de Desenvolvimento Científico e Tecnológico' (CNPq). This study was financed in part by the Coordenação de Aperfeiçoamento de Pessoal de Nível Superior Brasil (CAPES) - Finance Code 001.We are grateful to all the herbaria cited for giving us access to their collections. 


\section{Literature cited}

Berry, P.E., Hipp, A.L., Wurdack, K.J., Van Ee, B. \& Riina, R. 2005. Molecular phylogenetics of the giant genus Croton and tribe Crotoneae (Euphorbiaceae sensu stricto) using ITS and trnL-trnF DNA sequence data. American Journal of Botany 92: 1520-1534.

BFG. 2015. Growing Knowledge: an overview of Seed Plant diversity in Brazil. Rodriguésia 66: 1085-1113.

Caruzo, M.B.R. \& Cordeiro, I. 2007. Sinopse da tribo Crotoneae Dumort. (Euphorbiaceae s.s.) no Estado de São Paulo, Brasil. Hoehnea 34: 571-585.

Caruzo, M.B.R. \& Santos, R.F. 2015. First record of Croton echinocarpus (Euphorbiaceae: Crotoneae) in São Paulo state, Brazil. Check List 11: 1684

Caruzo, M.B.R., van Ee, B.W., Cordeiro, I., Berry, P.E. \& Riina, R. 2011. Molecular phylogenetics and the character evolution in "Sacaca" clade: novel relationships of Croton section Cleodora (Euphorbiaceae). Molecular Phylogenetics and Evolution 60: 193-206.

Gomes-Pompa, A. 1971. Possible papel de la vegetación secundaria en la evolución de la flora tropical. Biotropica 3: 125-135.

Govaerts, R., Frodin, D.G. \& Radcliffe-Smith, A. 2000. World Checklist and Bibliography of Euphorbiaceae (and Pandaceae), v. 2. Kew, Royal Botanical Gardens.

Hickey, L. J. 1973. Classification of the architecture of dicotyledonous leaves. American Journal of Botany 60: 17-33.

Riina, R., Berry, P.E. \& Van Ee, B.W. 2009. Molecular phylogenetics of the dragon's blood Croton section Cyclostigma (Euphorbiaceae): a polyphyletic assemblage unraveled. Systematic Botany 34: 360-374.

Santos, R.F., Riina, R. \& Caruzo, M.B.R. 2017. Diversity of arborescent lineages of Crotoneae (Euphorbiaceae) in the Brazilian Atlantic Rain Forest. Plant Syst Evol 303: 1467-1497.
Smith, L.B., Downs, R.J. \& Klein, R.M. 1988. Euforbiáceas. In: R. Reitz. Flora Ilustrada Catarinense (ed.). pp. 62-137.

Stearn, W.T. 1992. Botanical Latin. $4^{\mathrm{a}}$ ed. Timber Press, Portland.

Thiers, B. continuously updated. Index Herbariorum: A global directory of public herbaria and associated staff. New York Botanical Garden's Virtual Herbarium. The New York Botanical garden, New York. Available at http://sweetgum.nybg.org/ih/ (access in 4-XII-2018).

Van Ee, B.W., Riina, R. \& Berry, P.E. 2011. A revised infrageneric classification and molecular phylogeny of New World Croton (Euphorbiaceae). Taxon 60: 791-823.

Wanderley, M.G.L., Shepherd, G.J., Martins, S.E., Estrada, T.EM.D., Romanini, R.P., Koch, I., Pirani, J.R., Melhem, T.S., Harley, A.M.G., Kinoshita, L.S., Magenta, M.A.G., Wagner, H.M.L., Barros, F., Lohmann, L.G., Amaral, M.C.E., Cordeiro, I., Aragaki, S., Simão-Bianchini, R. \& Esteves, G.L. 2011. Checklist das Spermatophyta do Estado de São Paulo, Brasil. Biota Neotropica 11: 191-388.

Webster, G. L. 1992. Realignments in American Croton (Euphorbiaceae). Novon 2: 269-273.

Webster, G. L. 1993. A provisional synopsis of the sections of the genus Croton (Euphorbiaceae). Taxon 42: 793-823.

Webster, G. L. 1994. Systematics of the Euphorbiaceae. Annals of the Missouri Botanical Garden 81: 1-144.

Webster, G.L., Del-Arco-Aguilar, M.J. \& Smith, B.A. 1996. Systematic distribution of foliar trichome types in Croton (Euphorbiaceae). Botanical Journal of the Linnean Society 121: 41-57.

Wurdack, K.J., Hoffmann, P. \& Chase, M.W. 2005. Molecular phylogenetics analysis of uniovulate Euphorbiaceae (Euphorbiaceae sensu stricto) using plastid rbcL and trnL-F DNA sequences. American Journal of Botany 92:1397-1420. 